\title{
DEVELOPMENT OF E-LEARNING TEACHING MATERIALS ON MATRICES BASED ON COGNITIVE LOAD THEORY
}

\author{
Eliana $^{1}$, Hepsi Nindiasari ${ }^{2}$, Cecep Anwar Hadi Firdos Santosa ${ }^{3}$ \\ Universitas Sultan Ageng Tirtayasa, Jl. Raya Jakarta KM.4, Panancangan, Kec. Serang, Kota Jakarta, Banten, \\ 42124, (0254) 280330, Indonesia \\ e-mail: elianaaf1562@gmail.com
}

\begin{abstract}
Learning will be effective if it can minimize extraneous cognitive load because students' understanding can be improved and stored in long-term memory. The purpose of this study was to determine the development of elearning teaching materials on matrices based on cognitive load theory that is valid, practical, and effective. This teaching material development uses e-LKS (electronic student worksheet) with liveworksheet and presents example-based learning. This study uses the ADDIE development model. The development steps used are (1) analysis, (2) design, (3) development, (4) implementation, (5) evaluation. A valid test based on expert judgment shows that e-learning teaching materials on matrices based on cognitive load theory get an average of 4.25 with a very valid category so that this teaching material is feasible to use. The practicality test based on the student response questionnaire showed that this teaching material obtained an average of $79.7 \%$ with a good category. The evaluation test showed that this teaching material obtained an average of $78.6 \%$ with student completeness in learning, so it can be concluded that e-learning teaching materials on matrices based on cognitive load theory can be said to be effective.
\end{abstract}

Keywords: e-learning teaching materials, cognitive load theory, matrices

\begin{abstract}
Abstrak
Pembelajaran akan efektif jika dapat meminimalkan extraneous cognitive load karena pemahaman siswa dapat ditingkatkan dan menyimpan dalam memori jangka panjang. Tujuan penelitian ini adalah mengetahui pengembangan bahan ajar e-learning pada materi matriks berbasis cognitive load theory yang valid, praktis, dan efektif. Pengembangan bahan ajar ini menggunakan e-LKS (Lembar Kerja Siswa elektronik) dengan bantuan liveworksheet disajikan example-based learning. Penelitian ini menggunakan model pengembangan ADDIE. Langkah-langkah pengembangan yang digunakan adalah (1) analisis, (2) perancangan, (3) Pengembangan, (4) implementasi, (5) evaluasi. Uji valid berdasarkan pada penilaian para ahli menunjukan bahwa bahan ajar elearning pada materi matriks berbasis cognitive load theory memperoleh rata-rata sebesar 4,25 dengan kategori sangat valid sehingga bahan ajar ini layak untuk digunakan. Uji kepraktisan berdasarkan angket respon siswa menunjukkan bahwa bahan ajar ini memperoleh rata-rata sebesar 79,7\% dengan kategori baik, dan tes evaluasi menunjukkan bahwa bahan ajar ini memperoleh rata-rata sebesar $78,6 \%$ dengan ketuntasan siswa dalam pembelajaran sehingga dapat disimpulkan bahwa bahan ajar e-learning pada materi matriks berbasis cognitive load theory dapat dikatakan efektif.
\end{abstract}

Kata kunci: bahan ajar e-learning, cognitive load theory, matriks

\section{INTRODUCTION}

Determining teaching materials is the main part that must be determined by the teacher, the use of inappropriate teaching materials can affect the implementation of the learning process. In the Covid-19 pandemic situation, e-learning teaching materials are needed because distance learning is a learning solution and can take advantage of technology. The development of technology in education is a renewal of students' times, situations, 
conditions, and needs. E-learning teaching materials in mathematics learning by utilizing the internet can create a meaningful and enjoyable learning atmosphere (Agustina, Isnaini, \& Nery, 2016). Through e-learning learning, students are trained to be independent in terms of finding their materials or subject matter at certain times in order to increase their knowledge, play an active role in the learning process, and be more responsible for the learning process in order to increase their knowledge (Arifin, \& Herman, 2018).

In designing e-learning teaching materials, the teacher can attract students' attention and pay attention to students' cognition while learning. Learning is a process of changing the structure of knowledge from previously owned and stored knowledge in the brain through a reconstruction of old knowledge or by adding new knowledge. Learning in this sense is based on how the cognitive system works to understand knowledge in a meaningful way; therefore it is essential to understand how the cognitive system works when constructing knowledge and presenting teaching materials (Retnowati, 2008). Cognitive load is related to a person's mental effort when processing information (Santosa, Prabawanto, \& Marethi, 2019). The theory that talks about cognitive load are Cognitive Load Theory (CLT), proposed by John Sweller. Cognitive load theory is based on a cognitive architecture that contains limited working memory with a processing unit divided into two, namely visual information processing and audio information processing (Afidah, 2015).

The central part of the memory system that works in processing information are working memory and long-term memory. Cognitive load is the effort that must be made in working memory to process information received in a limited capacity. Long-term memory is a part of the memory system where information is stored over a long time. Working memory is a storage system that can contain a limited amount of information. All information is processed here before it is stored in long-term memory in schematic form because working memory limitations are very prone to overloading. When a cognitive load is too heavy, the learning process can be hampered (Santosa et al., 2018).

Three sources cause cognitive load in working memory: intrinsic cognitive load, extraneous cognitive load, and germane cognitive load (Sweller, 2010). Three things need to be considered in cognitive load: managing intrinsic cognitive load, minimizing extraneous cognitive load, and increasing germane cognitive load (Fuadi, Maman, \& Hendrayana, 2019). Learning will be effective if it can reduce the extraneous cognitive load (Kamaruddin, 2016). 
To reduce the extraneous cognitive load, this teaching material is compiled in e-LKS (electronic student worksheet) with the help of a liveworksheet. Designing learning must involve human cognitive architecture so that effective and efficient learning must be in line with information processing principles (Sweller, 2008). Learning as a system consists of some organized components, including learning objectives, learning materials, learning strategies, and methods, learning media or teaching aids, class organizing, and learning evaluation. This teaching material uses e-LKS, which is presented by example-based learning with the effect of working example.

Example-based learning in e-LKS is divided into two types: Example-based learning with an explanation, which means explaining the steps for solving the problem given, and Examplebased learning with prompting explanation, which means learning with examples accompanied by directions prompting on each step of completion. Using the worked example reduced the extrinsic cognitive load but did not guarantee that this effect would also increase the cognitive load of germane. Using a worked example is believed to help students understand the material that has been taught by encouraging students to do self-explanations (Santosa, Prabawanto, \& Marethi, 2019). With the application of e-LKS, which is presented with example-based learning, it is hoped that it can minimize or decrease extraneous cognitive load because student understanding can be improved and stored in long-term memory so that the teaching materials are arranged according to the thinking capacity of students.

Revealing the research process using a qualitative approach with the results shows that the material's complexity causes the intrinsic cognitive load, namely difficulty imagining, difficulty performing algebraic operations, difficulty determining triangle congruence, and difficulty determining angles. Extraneous cognitive load is caused by the teacher's way of explaining too quickly and the distraction of some noisy or rowdy friends. Germane's cognitive load is caused by the use of Cabri 3D in learning and giving practice questions (Yohanes, Subanji, and Sisworo, 2016). Based on the background above description, the writer wants to do research entitled "Development of E-Learning Teaching Materials on Matrices Based on Cognitive Load Theory". The objectives of this study are:

1. Produce e-learning teaching materials on matrices based on cognitive load theory. 
2. Knowing the effectiveness of e-learning teaching materials on matrices based on cognitive load theory.

\section{METHODS}

This development research uses the ADDIE research design, which consists of: analysis, design, development, implementation, evaluation. This research was conducted on students of SMK (vocational high school) class XI AK1. The stages carried out by researchers in this development are as follows:

1. Analysis

The analysis process is very important in terms of this development because the analysis results are a reference in making teaching materials. At this stage, the student needs analysis was conducted at SMK YP IPPI Petojo.

2. Design

After observing and gathering information, the next stage is the design or design stage. At this stage, the researcher made initial preparations, including KD analysis, the material to be studied, formulated basic ability indicators, designed teaching materials in the form of e-LKS then consulted with the supervisor. Simultaneously, the teaching material assessment instrument was validated by experts to obtain a valid assessment instrument.

3. Development

The development step can include activities to create and modify teaching materials to achieve predetermined learning objectives. At this stage, the researcher designs or preliminary designs on the actual appearance.

4. Implementation

The implementation in this study is a process of testing teaching materials in classroom learning. Teaching materials and instruments that have been revised based on input from the validator and are declared feasible can begin to become research objects. The application of teaching materials in the classroom is carried out to determine the teaching materials' activeness and practicality.

5. Evaluation

This step is a process carried out to provide value to the product being developed. The evaluation of teaching materials in this study was carried out based on validation Vol. 5, No. 1, January 2021, 47-63 
sheets, student response questionnaires, and the results of the effectiveness of e-learning teaching materials. After going through the evaluation and refinement stages can produce scores obtained from all experts and respondents.

The data analysis techniques used in this study are as follows:

1. Analysis of the validity sheet

Validation of e-learning teaching materials based on cognitive load theory will be carried out using experts. The data obtained from the results of expert validation were analyzed using analysis techniques according to the Khabibah (Sumiaty, Astuti, \& Suratman, 2019) as follows:

a. Average criteria of each validator:

$$
K_{i}=\frac{\sum_{j=i}^{n} V_{j i}}{n}
$$

where

$V_{j i}=$ the data of the $j$-th validator value for the $i$-th indicator

$n$ = number of validators

b. Average aspect of indicators:

$$
A_{i}=\frac{\sum_{j=i}^{n} K_{j i}}{n}
$$

where

$A_{i}=$ average for the $i$-th aspect

$K_{j i}=$ average for the $i$-th aspect of the $j$-th indicator

$n=$ number of indicators in the $i$-th aspect

c. Average total validator for each aspect of the media:

$$
V_{a}=\frac{\sum_{i=1}^{n} A_{i}}{n}
$$

where

$V_{a}=$ average for each aspect

$n$ = number of aspects 
d. Validity criteria

Table 1. Validity Criteria

\begin{tabular}{cc}
\hline Score & Validity Criteria \\
\hline $4-5$ & Very valid \\
$3-4$ & Valid \\
$2-3$ & Less valid \\
$1-2$ & Invalid \\
\hline
\end{tabular}

2. Analysis of student questionnaires

The steps used to provide the questionnaire criteria for the practicality of teaching materials are as follows (Pangesti, \& Retnowati, 2017):

a. recap the total score from the practicality sheet that the students had filled in for each statement

b. calculate the average score of each statement from the practicality questionnaire sheet that has been filled in by students, with the formula

$$
R s=\frac{\sum \text { score for each item }}{n}
$$

c. questionnaire criteria for the practicality of teaching materials

Table 2. Questionnaire Criteria for The Practicality of Teaching Materials

\begin{tabular}{cc}
\hline Score & Categories \\
\hline $4,21-5,00$ & Very Practical \\
$3,41-4,20$ & Practical \\
$2,61-3,40$ & Practical enough \\
$1,81-1,60$ & Not Practical \\
$1,00-1,80$ & Very not Practical
\end{tabular}

Teaching materials are said to meet the practical aspect if the minimum average assessment is in the "Good" criteria (Pangesti \& Retnowati, 2017).

Table 3. Questionnaire Criteria for The Practicality of Teaching Materials

\begin{tabular}{cc}
\hline Interval & Criteria \\
\hline $\mathbf{2 9 1}$ & Very Good \\
$78-90$ & Good \\
$65-77$ & Good enough \\
$51-64$ & Not Good \\
$\leq \mathbf{5 0}$ & Very not Good \\
\hline
\end{tabular}

\section{RESULTS AND DISCUSSION}

The results of the research are based on the following development stages:

1. Analysis 
In this stage, the researcher analyzed several things to provide an overview of the developed teaching materials. The analysis process is very important in terms of this development because the analysis results are a reference in making teaching materials. At this stage the needs analysis was carried out at SMK YP IPPI Petojo. The analysis carried out to support the development process is as follows:

a. Analysis of teaching material needs

In determining the analysis of teaching material needs, observations were made. It aims to find out the teaching materials that are needed by students during the Covid-19 pandemic. This study's needs analysis was carried out in several stages, namely the observation of learning activities and the learning tools used. This research was conducted in class XI AK 1 . From the above problems, one of the teaching materials to overcome the existing problems is to make e-learning teaching materials in e-LKS.

b. Analysis of material

After selecting the type of teaching materials developed, the researcher then selects the teaching materials to be developed. The material selection was carried out by consulting and discussing with the mathematics teacher at SMK YP IPPI Petojo. The material chosen is the Matrix because this material has not been studied, and usually students have difficulty understanding the material.

c. Analysis Curriculum

At this stage, an analysis of the SMK mathematics curriculum was carried out. The curriculum analysis includes analysis of Basic Competencies (KD), indicators, and learning objectives that students must achieve. The analysis is carried out so that the teaching materials are arranged according to the needs and match the basic competencies students must achieve in learning.

2. Design

After observing and gathering information, the next stage is the design or design stage. This stage consists of planning teaching materials and compiling teaching material assessment instruments.

a. Planning of teaching material 
Planning of the content of teaching materials and the order in which the material is presented. Under the curriculum analysis carried out in the previous stage, this elearning teaching material is expected to help teachers teach during the Covid-19 pandemic using Google Classroom media. e-LKS, with the help of a liveworksheet is presented with example-based learning.

b. Developing of teaching material assessment instruments

At this stage, the researchers compiled a validated teaching material assessment instrument for experts to obtain a valid teaching material assessment instrument. The validation sheet consists of five answer choices with scores of $5,4,3,2$, and 1 , respectively. The teaching material assessment instrument consists of 15 points of assessment covering several aspects: material presentation, language, and media presentation. After the instrument was made, the instrument was consulted with the supervisor, then it was validated by the experts who reviewed the questionnaire.

3. Development

The development step includes activities to create and modify teaching materials to achieve predetermined learning objectives. At this stage, the researcher translates the initial design or design into its actual appearance. The purpose of this stage is to obtain the initial product.

a. Developing of teaching materials

In this step, the preparation of teaching materials is carried out online using Google Classroom media. Designing learning must involve human cognitive architecture so that learning is effective and efficient. Developing this teaching material using e-LKS, which is presented by example-based learning with worked example effects. Example-based learning can be used to reduce the cognitive load. Example-based learning presents completion steps that lead to a final solution. Example-based learning in e-LKS is divided into Example-based learning with explanation and Example-based learning with explanation prompting. E-LKS with the help of www.liveworksheets.com. The E-LKS is divided into three with the following links:

a) Student worksheet 1 with definition material and transpose matrix link e-LKS 
https://www.liveworksheets.com/c?a=s\&t=jxciz07rvf\&mn=xz\&m=n\&is=y\&ia=y

\section{$\& \mathrm{l}=\mathrm{fi} \& \mathrm{i}=\mathrm{uzxoxxd \& r}=\mathrm{dn}$}

b) Student worksheet 2 with the e-LKS matrix link similarity material

https://www.liveworksheets.com/c?a=s\&t=jxciz07rvf\&mn=nz\&m=n\&is=y\&ia=y\&l $\underline{z z k i=u z f n n f z \& r=x j}$

c) Lembar kerja siswa 3 dengan materi operasi matriks link e-LKS

https://www.liveworksheets.com/c?a=s\&t=jxciz07rvf\&mn=xz\&m=n\&is=y\&ia=y\&| =up\&i=uzxoonz\&r=za dan

https://www.liveworksheets.com/c?a=s\&t=jxciz07rvf\&mn=xz\&m=n\&is=y\&ia=y\&l $=x f \& i=u z x o n x t \& r=v m$

The following is a picture of e-LKS with the help of a direct worksheet presented with Example-based learning.

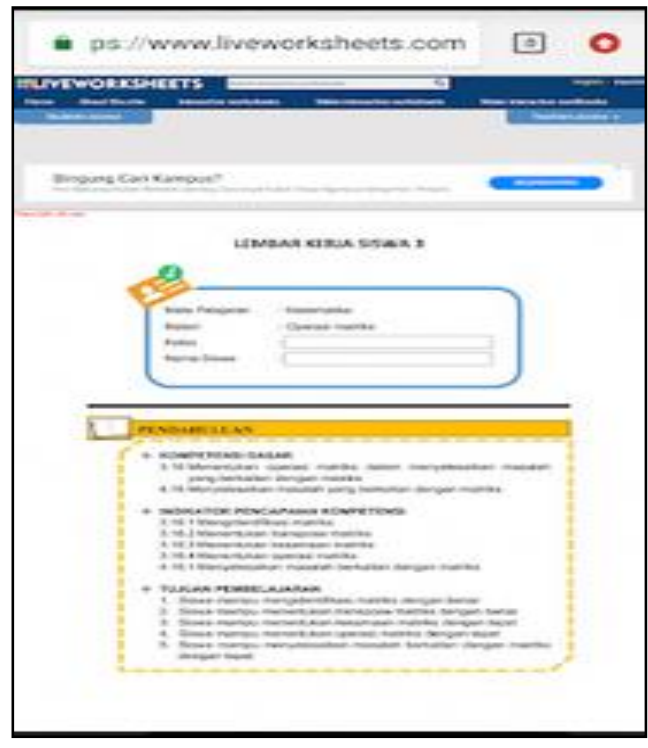

Figure 1. Initial View of e-LKS

Figure 1 is the initial stage of Example-based learning. Students are introduced to the introduction of basic competencies, indicators of competency achievement, and learning objectives as prerequisites for matrix material before students are given problems to solve in the initial display of e-LKS, which consists of student identity, time for e-LKS processing and introduction. The following is a display of one of the e-LKS that is given a problem to be solved by students presented with example-based learning. 


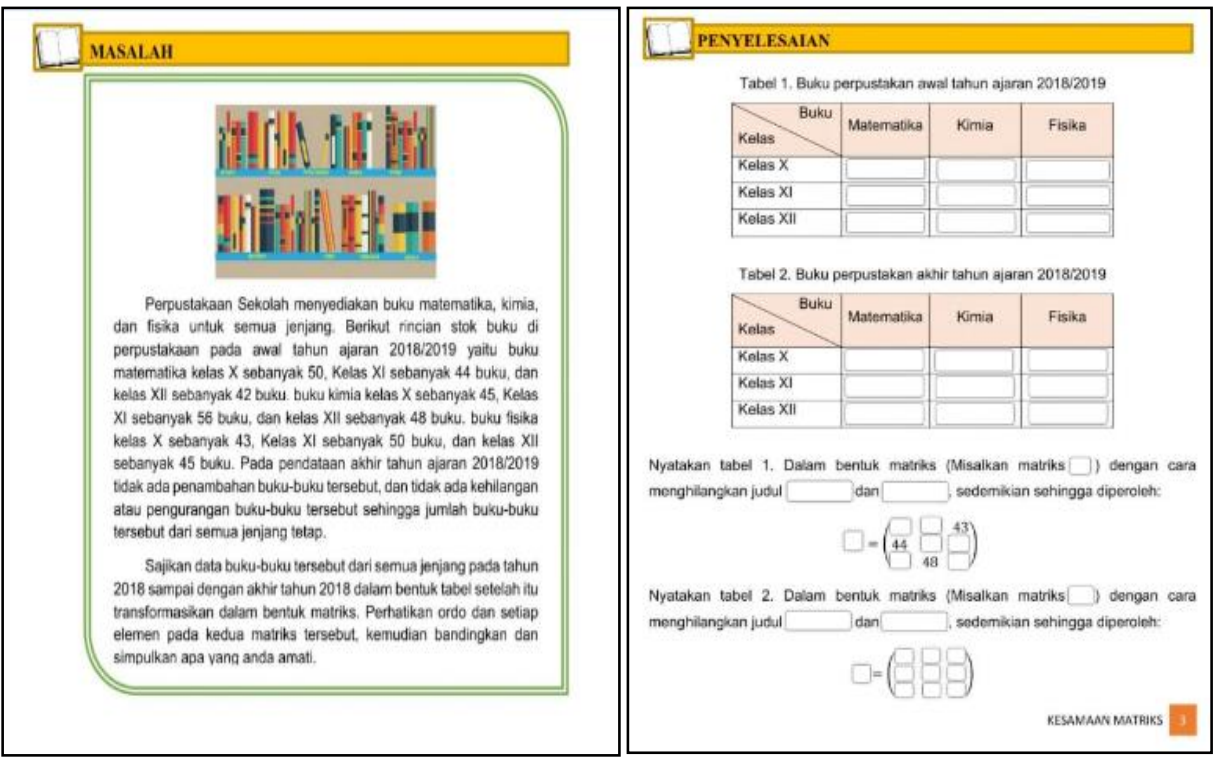

Figure 2. Example-Based Learning with Explanation

In Figure 2 example-based learning used is incomplete. Example-based learning with explanations makes examples of learning. Example-based learning with explanations to provide an explanation of the steps for solving a given problem. The way it is done, students read and understand the problems presented. Students solve the problem by filling in the answers in the space provided. If the student has completed or has already filled in all the answers, the student can click finish.

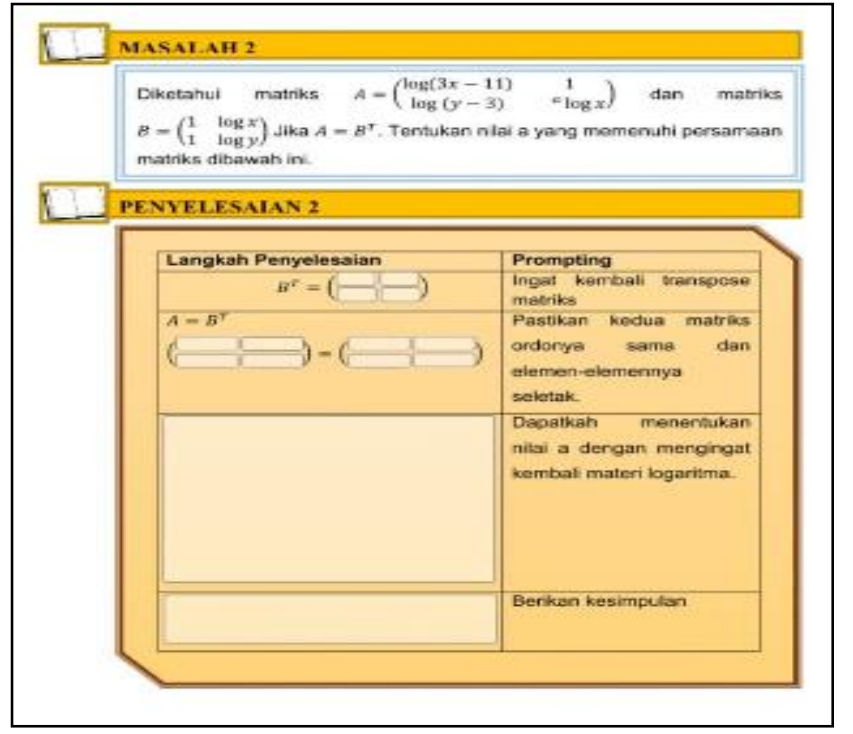

Figure 3. Example-Based Learning with Explanation Prompting

In Figure 3, the example-based learning used is incomplete. Example-based learning with explanation prompting makes examples of learning. Example-based learning with explanation prompting is learning with examples accompanied by 
prompting directions at each completion step. The way it is done, students read and understand the problems presented. Students solve the problem by filling in the answers in the space provided. If the student has completed or has already filled in all the answers, they can click finish. After clicking finish, a display will appear that can be seen in Figure 4.

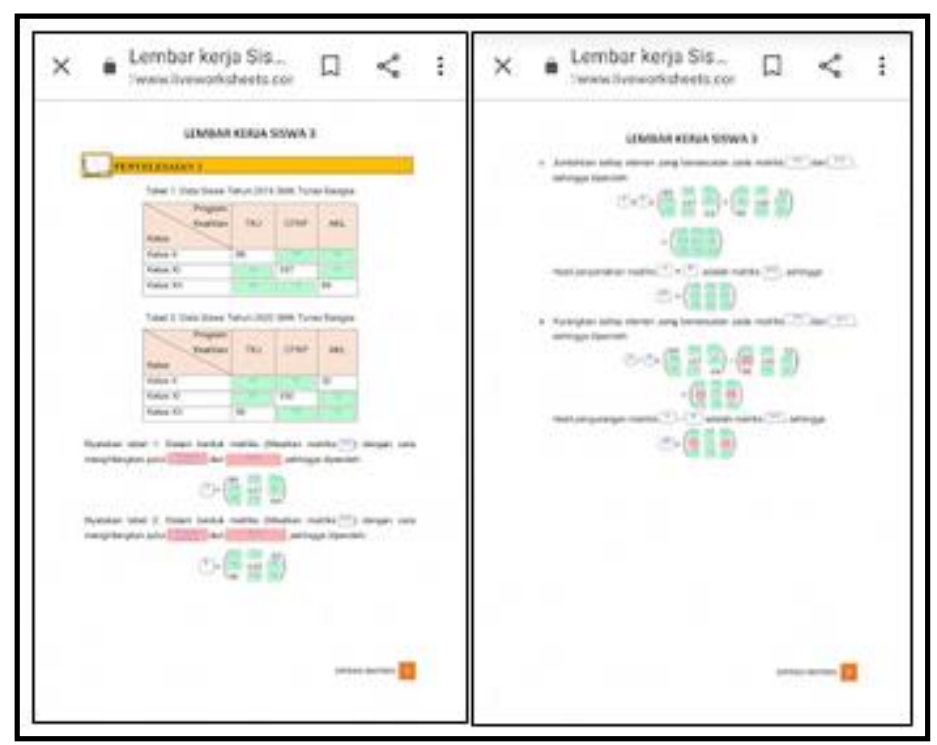

Figure 4. The View After Clicking Finish

In Figure 4, after the students click finish there is a red and green color display. The red color means that the student is doing it wrong, while the green color means that the student is doing it right. This means that students can see to what extent the understanding of the material in the examples of completion has been given.

Worked examples are structured steps to complete. The following are the effects of designing worked example.

a) Split-attention effect

Split-attention results from presenting multiple sources of information separately. This affects the design effectiveness of the worked example so that it increases the cognitive load of students.

b) Redudancy effect

The redundancy effect occurs when several sources of information have the same meaning, causing overlapping information. Also, restating information that is well understood by students also causes a redundancy effect, which can increase the student's cognitive load. 
c) Contiguity effect

Present writing and pictures or tables at the same time. Students learn better when writing and related pictures or tables are presented simultaneously.

d) Segmenting effect

Divide e-LKS into three student worksheets with each student worksheet with different material.

4. Implementation

Implementation is the fourth step in the ADDIE development method. The implementation in this study is a process of testing teaching materials in classroom learning. Teaching materials and instruments that have been revised based on input from the validator and declared feasible can begin to become research objects. The application of teaching materials in the classroom is carried out to determine the teaching materials' activeness and practicality.

5. Evaluation

The final or fifth step of the ADDIE development model is evaluation. Evaluation is a process carried out by someone to provide an assessment of something, in this case the quality of learning teaching materials. Evaluation of teaching materials in this study was carried out based on expert validation sheets, and student response questionnaires and test results on learning teaching materials. This assessment will be used as a reference in determining the feasibility of the learning module being developed.

The results of the assessment of learning teaching materials will be explained as follows:

1. Results of Validation Sheet Data Analysis

Validation of e-learning teaching materials based on cognitive load theory will be carried out using experts. The data obtained from the results of expert validation were analyzed employing analysis techniques according to Khabibah. The following are the results of calculating the validation sheet by experts, which are shown in Table 4.

Table 4. Calculation of Validation Sheet

\begin{tabular}{lcccc}
\hline Validator & Aspect 1 & $\begin{array}{c}\text { Average } \\
\text { Aspect 2 }\end{array}$ & $\begin{array}{c}\text { Total average } \\
\text { (Va) }\end{array}$ \\
\hline $\begin{array}{l}\text { Validator 1 } \\
\text { Validator 2 } \\
\text { Validator 3 } \\
\text { Validator 4 }\end{array}$ & 4,33 & 4,0 & 4,40 & 4,25 \\
\hline
\end{tabular}




\begin{tabular}{lllll}
\hline Validator 5 & & & \\
Validator 6 & & & \\
Categories & Very valid & Very valid & Very valid & Very valid \\
\hline
\end{tabular}

Based on Table 4, it can be seen that aspect 1, namely the presentation of material with an average of 4.33 , is included in the very valid category, aspect 2 , namely language with an average of 4.0 , is included in the very valid category, aspect 3 is the presentation of media with an average 4.40 is included in the very valid category. The total average validity of 4.25 is included in the very valid category. Overall, the learning-teaching materials developed are in the very valid category. It can be concluded that the e-LKS presented by example-based learning can be said to be suitable for use in research.

2. Analysis of Student's Questionnaire Response Data

The following are the results of calculating student responses to teaching materials shown in Table 5.

Table 5. Calculation of Student Response Questionnaires

\begin{tabular}{ccc}
\hline Item Number & Average item score & Categories \\
\hline 1 & 4,32 & Very practical \\
2 & 4,11 & Practical \\
3 & 3,96 & Practical \\
4 & 3,79 & Practical \\
5 & 4,29 & Very practical \\
6 & 3,93 & Practical \\
7 & 4,07 & Practical \\
8 & 4,46 & Very practical \\
9 & 4,00 & Practical \\
10 & 3,82 & Practical \\
11 & 4,11 & Practical \\
12 & 3,71 & Practical \\
13 & 3,71 & Practical \\
14 & 4,11 & Practical \\
15 & 3,75 & Practical \\
16 & 4,04 & Practical \\
17 & 3,79 & Practical \\
18 & 4,11 & Practical \\
19 & 3,96 & Practical \\
20 & 3,71 & Practical \\
Total Average & 79,75 & Good \\
\hline
\end{tabular}

Based on Table 5, it can be seen that the student questionnaire responses are included in the practical category of item number items $2,3,4,6,7,9,10,11,12,13,14$, $15,16,17,18,19$, and 20 , and those included in the very practical category item number 
items 1,5 , and 8 . It was concluded that students responded positively to e-LKS. average 79.75 .

3. Evaluation Test Data Analysis

The following are the results of calculating the student evaluation test on teaching materials shown in the table.

Table 6. Percentage of Students' Accomplishment

\begin{tabular}{ccc}
\hline Categories & Total & Percentage \\
\hline Unaccomplished & 6 students & $21,4 \%$ \\
Accomplished & 22 students & $78,6 \%$ \\
Total & 28 students & \\
\hline
\end{tabular}

Based on Table 3. that the percentage of accomplishment data obtained $78.6 \%$ of students complete. A total of 22 students were declared complete, and 6 students had not. Thus, teaching materials are said to be effective if $75 \%$ of students get the same or more minimum completeness criteria (KKM). It was concluded that the e-LKS presented by example-based learning could be said to be effective in class XI AK 1 . This teaching material is designed so that there is no longer a cognitive load on students. Student learning is meaningful if there are more examples or exercises to understand better and be ready to receive new material. With the introduction of e-LKS presented by examplebased learning, it is hoped that it can reduce extraneous cognitive load because students can understand and store it in long-term memory.

Example-based learning is learning contained in cognitive load theory. In the early stages of the learning process, students have low-level knowledge. When students are faced with a problem to be solved students cannot answer because it creates an unproductive cognitive load, so there is little or no space capacity left for the process of understanding. Conversely, when students study example-based learning, they can concentrate on understanding because students have existing cognitive abilities and accept new cognitive abilities through the examples given. It was also expressed by (Pangesti, \& Retnowati, 2017) designing and testing alternative learning strategies, one of which is the worked example effect strategy. This strategy is effectively used to prevent increased cognitive load.

Effective learning can be achieved by managing intrinsic cognitive load, minimizing extraneous cognitive load and increasing germane cognitive load. This was also expressed 
by (Kurniawati, Hadi, \& Rulviana, 2018) which stated that difficult material, if it can be delivered easily and excitingly, can reduce extraneous cognitive load and manage intrinsic cognitive load so that students can easily understand the material. Reducing the extraneous cognitive load, the information processing process for students can be more effective so that the learning process is also more effective (Wantika, 2017).

This teaching material or e-LKS with the help of a liveworksheet has advantages. Namely, students can directly fill in the answers to the assignment given by the teacher, students can find out to what extent students understand the material in a way that students can see which answers are correct and which are wrong, and given examplebased learning students can understand the material by reducing the cognitive load on students. As for the weaknesses of this teaching material, because using an internet connection, sometimes students cannot see which answers are right and which are wrong so it depends on the stability of the internet connection.

\section{CONCLUSION}

Based on the results of the development of e-learning teaching materials on matrix material based on cognitive load theory, it can be concluded that this research and development has resulted in e-learning teaching materials on matrix material based on cognitive load theory. This teaching material is arranged in the form of e-LKS with the help of liveworksheet, which is presented with example-based learning. Example-based learning can be used to reduce the cognitive load. Example-based learning presents completion steps that lead to a final solution.

The validation test based on experts' judgment shows that this teaching material obtains an average of 4.25 with a very valid category so that this teaching material is suitable for use. The practicality test based on the student response questionnaire showed that this teaching material obtained an average of $79.7 \%$ with a good category, and the evaluation test showed that this teaching material obtained an average of $78.6 \%$ with student completeness in learning, so it can be concluded that E-learning teaching materials in the matrix material based on cognitive load theory can be said to be effective in class XI AK 1.

Based on the research results that have been done, the researcher's suggestions for the next researcher. Expanding the trial population and sample under study, not just limited to 
one class, the expansion of the material presented in teaching materials is not only limited to matrix material but needs to pay attention to the cognitive load of students, looking for other suitable learning solutions to reduce student cognitive load, and developing teaching materials innovative learning and using newer and better technology with attention to students' cognitive abilities.

\section{REFERENCES}

Afidah, V. N. (2015). Prinsip- Prinsip Teori Beban Kognitif Dalam Merancang Media Pembelajaran Matematika. JP2M. Vol 1(1), 72-79.

Agustina., Isnaini, M., dan Nery, R.S. (2016). Pengembangan Bahan Ajar Matematika Menggunakan Edmodo Pada Materi Fungsi. JPM RAFA. Vol. 2(1), 123-141.

Arifin, F., dan Herman, T. (2018). Pengaruh Pembelajaran E-Learning Model Web Centric Course Terhadap Pemahaman Konsep Dan Kemandirian Belajar Matematika Siswa. Jurnal Pendidikan Matematika. Vol. 12(2). 1-12

Fuadi., Maman, F., dan Hendrayana, A. (2019). Pengaruh Pembelajaran Rigorous Mathematical Thingking (RMT) Terhadap Beban Kognitif Konstruktif dan Kompetensi Strategis Matematis Siswa di Pondok Pesantren. JPPM. Vol. 12 (1). 32-50.

Kamaruddin. (2016). Penerapan Pembelajaran Statistika 2 Mengacu Pada Teori Beban Kognitif Pada Mahasiswa Matematika Universitas Kaltara Tahun Ajaran 2015/2016. In Seminar Nasional Matematika Dan Pendidikan Matematika, (95-100). Yogyakarta: UNY.

Kurniawati, R. P., Hadi, F. R., dan Rulviana, V. (2018). Pengembangan Multimedia Pembelajaran Berbasis Cognitive Load Theory (CLT) Pada Materi Volume Kubus dan Balok di Sekolah Dasar. Aksioma. Vol. 7 (2). 314-323.

Pangesti, F. T. P., dan Retnowati, E. (2017). Pengembangan Bahan Ajar Geometri SMP Berbasis Cognitive Load Theory Berorientasi pada Prestasi Belajar Siswa. Pythagoras. Vol. 12(1). 33-46.

Retnowati, E. (2008). Keterbatasan memori dan implikasinya dalam mendesain metode pembelajaran matematika. In Seminar Matematika dan Pendidikan Matematika. Yogyakarta: UNY.

Santosa, C. A. H. F., Prabawanto, S., dan Marethi, I. (2019). Fostering Germane Load Through Self-Explantion Prompting in Calculus Instruction. Indonesian Journal on Learning and Advanced Education. Vol. 1 (1). 37-47. https://doi.org/10.23917/ijolae.v1i1.7421 
Santosa, dkk. (2018). The Role Of Worked-Example In Enhancing Students Self-Explanation And Cognitive Efficiency In Calculus Instruction. Jurnal Riset Pendidikan Matematika. Vol. 5 (2). 168-180.

Sumiaty, Astuti, dan Suratman. (2019). Pengembangan Modul Berbasis Web Untuk Pembelajaran IImu Pengetahuan Sosial Terpadu Kelas IX SMP. Perspektif IImu Pendidikan. Vol. 33 (2). 147-156.

Sweller, J. (2008). Human Cognitive Architecture. Handbook of Research on Educational Communications and Technology $\left(20,3^{\text {rd }}, 369-381\right)$.

Sweller, J. (2010). Element Interactivity and Instrinsic, Extraneous, and Germane Cognitive Load. Educational Psychology Review, 22(22), 1223-138

Wantika, R. R. (2017). Pembelajaran Kooperatif Tipe TAI Berdasarkan Teori Beban Kognitif. Jurnal Buana Pendidikan. Vol. 12 (23). 43-48.

Yohanes, B., Subanji., dan Sisworo. (2016). Beban Kognitif Siswa Dalam Pembelajaran Materi Geometri. Jurnal Pendidikan : Teori, Penelitian, dan Pengembangan. Vol. 1(2). 187-195. 